\title{
Potential targets for the hepatitis C virus-mediated autoimmune thyroiditis
}

\author{
Potenciais alvos para a tireoidite autoimune mediado pelo vírus da hepatite $\mathrm{C}$ \\ Luís Jesuíno de Oliveira Andrade ${ }^{1}$ (D), Luisa Correia Matos de Oliveira² (D), Gabriela Correia Matos de Oliveira ${ }^{3}$
}

\begin{abstract}
Introduction: The mechanisms by which hepatitis C virus (HCV) infection induces autoimmune thyroiditis (AIT) have been studied, and it was suggested that inflammatory cytokines during HCV infection would change the thyroperoxidase (TPO) signaling cascade and thyroglobulin ( $\mathrm{Tg}$ ) determining autoimmune thyroid disease.

Objective: To show the signaling pathway, of TPO and $\mathrm{Tg}$, and their potential targets mediated HCV in individuals with hepatitis $\mathrm{C}$.

Methods: The mapping of the signaling pathway was based on a review study approach and performed using the automatic annotation server of the Kyoto and Genome Encyclopedia (KEGG). PathVisio is free software for analysis and design of open source routes, and was used for the graphic representation of the signaling pathway.

Results: The contigs were extracted from the KEGG database and their mapped transcription represents the signaling pathway of the main biomolecules that triggers the AIT. The action of HCV, or its treatment can trigger AIT that is characterized by the presence of autoantibodies against TPO and Tg. In AIT, autoreactive CD4 + T lymphocytes recruit $B$ cells and $C D 8+T$ cells in the thyroid. The progression of the disease leads to the death of thyroid cells and hypothyroidism.

Conclusion: HCV or its treatment activates several signaling pathways with thyroid cells damage resulting in AIT and secondary hypothyroidism to cellular apoptosis.
\end{abstract}

Key words: Autoimmune thyroiditis, Hepatitis C virus, Signaling pathway.

\section{RESUMO}

Introdução: Os mecanismos pelos quais a infecção com o vírus da hepatite $\mathrm{C}(\mathrm{HCV})$ induz à tireoidite autoimune (TAI) têm sido alvo de estudos. Tem sido sugerido que citocinas inflamatórias, como a elevação das interleucinas na inflamação causadas pelo HCV, alterariam a cascata de sinalização da tireoperoxidase (TPO) e tireoglobulina (Tg) determinando um quadro de doença autoimune da tireóide.

Objetivo: Demonstrar a via de sinalização da TPO e da Tg e seus potenciais alvos para a TAI mediados pelo HCV em indivíduos com hepatite $C$.

Método: O mapeamento da via de sinalização foi realizado usando o servidor de anotação automática da Enciclopédia Quioto de Genes e Genomas (KEGG). O PathVisio, um software gratuito de análise e desenho de vias de código aberto, foi utilizado para a representação gráfica da via de sinalização.

Resultado: As sequências foram retiradas do banco de dados KEGG e sua transcrição mapeada representa a via de sinalização das principais biomoléculas que desencadeia a TAI. A ação do HCV, ou seu tratamento pode desencadear a TAI que é caracterizada pela presença de autoanticorpos contra a TPO e Tg. Na TAI os linfócitos T CD4+ auto-reativos recrutam células $B$ e células $T C D 8+$ na tireóide. A progressão da doença leva à morte de células da tireóide e hipotireoidismo.

Conclusão: O HCV ou o seu tratamento ativa várias vias de sinalização com dano na célula tireoidiana, tendo como resultado TAI e hipotireoidismo secundário a apoptose celular.

Palavras-chaves: Tireoidite autoimune, Vírus da hepatite C, Via de sinalização.

\footnotetext{
Universidade Estadual de Santa Cruz. Departamento de Saúde. Ilhéus, (BA), Brazil.

Centro Universitário SENAI CIMATEC . Salvador , (BA), Brazil.

Faculdade de Medicina - UniFTC. Salvador - (BA), Brazil.
} 


\section{INTRODUCTION}

Signaling pathway, also called signal transduction cascades, is defined how the aggregation of molecules in a cell that regulates one or several functions of protection against damage to cell. ${ }^{1}$

The thyroid hormone has a signaling pathway complex with multiple interactions being highly regulated due to tissue-specific thyroid cell expression, beyond cross-talk with other signaling pathways. ${ }^{2}$ Thyroid peroxidase (TPO) is an enzyme and along with thyroglobulin $(\mathrm{Tg})$ are involved in the thyroid hormone synthesis.

The autoimmune thyroiditis (AIT) is characterized by lymphocytic infiltrates with progressive destruction of thyroid follicles and production of antithyroglobulin and antithyroperoxidase antibodies (TPO-Ab). ${ }^{3}$

The hepatitis $\mathrm{C}$ virus ( $\mathrm{HCV}$ ) infection is associated to endocrine-metabolic disorders including AIT. ${ }^{4}$ Studies have shown that the therapy for HCV induces thyroid diseases, and female sex, positive TPO-Ab and elevated serum of thyroid-stimulating hormone (TSH) concentration are important risk factors for AIT development. ${ }^{5}$ It has been suggested that the elevation of interleukins (IL) in inflammation caused by $\mathrm{HCV}$ would alter the signaling cascade of TPO and Tg determining autoimmune thyroid disease. ${ }^{6}$

In this study, we show the signaling pathway of TPO and Tg, and their potential targets for the HC$\mathrm{V}$-mediated AIT based on a review of the literature.

\section{METHOD}

For search signaling pathways we use the Kyoto Encyclopedia for Genes and Genomes (KEGG) pathway as reference. The KEGG is a database where they found maps of biological interactions with cellular processes and pathways related to signal transduction, the understanding of functions of a cell from molecular-level information. ${ }^{7}$

PathVisio (version 3.2.4) is free software for biological pathways and design of open source routes, and was used for the graphic representation of the signaling pathway because it is a tool that enables displaying and editing of biological signaling pathways. ${ }^{8}$

Access numbers with the respective FASTA sequences as input to obtain the cell signaling pathway were queried at the National Center for Biotechno- logy Information, and HCV genotypes that showed amino acid similarity to tg, TPO, and thyrotropin receptor were evaluated. The six HCV genotypes were evaluated: hepatitis C virus subtype $1 \mathrm{a}$ - GenBank: LC209888.1, hepatitis C virus subtype 1b - GenBank: ACE82442.1, hepatitis C virus subtype 1c - UniProtKB/Swiss-Prot: Q81754.3, hepatitis C virus subtype 2a - GenBank: AGZ91309.1, hepatitis C virus subtype 2b - GenBank: ADQ73656.1, hepatitis $C$ virus subtype 2c - GenBank: AFN53801.1, hepatitis C virus subtype 2d - GenBank: AAA67817.1, hepatitis $C$ virus subtype 2e - GenBank: ADG27686.1, hepatitis C virus subtype 2f - GenBank: ADG27630.1, hepatitis C virus subtype 3a - UniProtKB/Swiss-Prot: Q81495.3, hepatitis C virus subtype 3b - GenBank: BAI79035.1, hepatitis C virus subtype $3 \mathrm{~g}$ - GenBank: AFN53790.1, hepatitis C virus subtype 4a - GenBank: ABF60957.1, hepatitis C virus subtype 4c - GenBank: AAB02117.1, hepatitis C virus subtype 4d - GenBank: AHH29580.1, hepatitis C virus subtype $4 \mathrm{f}$ - GenBank: ABU68272.1, hepatitis C virus subtype 5a - GenBank: CBF60990.1, hepatitis C virus subtype 6a - GenBank: ADY38591.1, hepatitis C virus subtype $6 \mathrm{~h}$ - GenBank: ADG28673.1, hepatitis $C$ virus subtype $6 \mathrm{k}$ - GenBank: ABB84855.1, and hepatitis $C$ virus subtype $6 n$ - GenBank: ABB84856.1. In relation to tissue-specific thyroid self-protein the $\mathrm{Tg}$ NP_003226.4, TPO - NP_001193673.1, and thyrotropin receptor - GenBank: AAB23390.2 were evaluated.

A concise map of the signaling pathway of TPO and Tg, and their potential targets for the hepatitis C virus-mediated AIT was developed based on a set of confidence criteria is also available at www. genome.jp/kegg-bin/show_pathway?hsa05320.

The connections were elaborated among all the molecules found in the literature evaluated. When the molecules recognized in the literature didn't have their interactions identified, the KEGG database was used to search for unidentified connections.

For the design of signaling pathway started with a schematic overview of all pathway maps where each pathway of HCV and of the AIT. Following an overview, started in a specific pathway and the drawing may then be extended step by step with additional linked pathways.

\section{RESULT}

The HCV is an etiological factor of AIT because it may infect thyroid follicular cells, which presents 
CD8+ T-cells responses to HCV antigens expressed on a cell membrane, induced by a major histocompatibility complex (MHC) class II antigens DR expression, or non-specific secretion of interleukin production. Presumably, the HCV would alter immune regulatory signaling pathways allowing AIT to emerge (Figure 1 ).

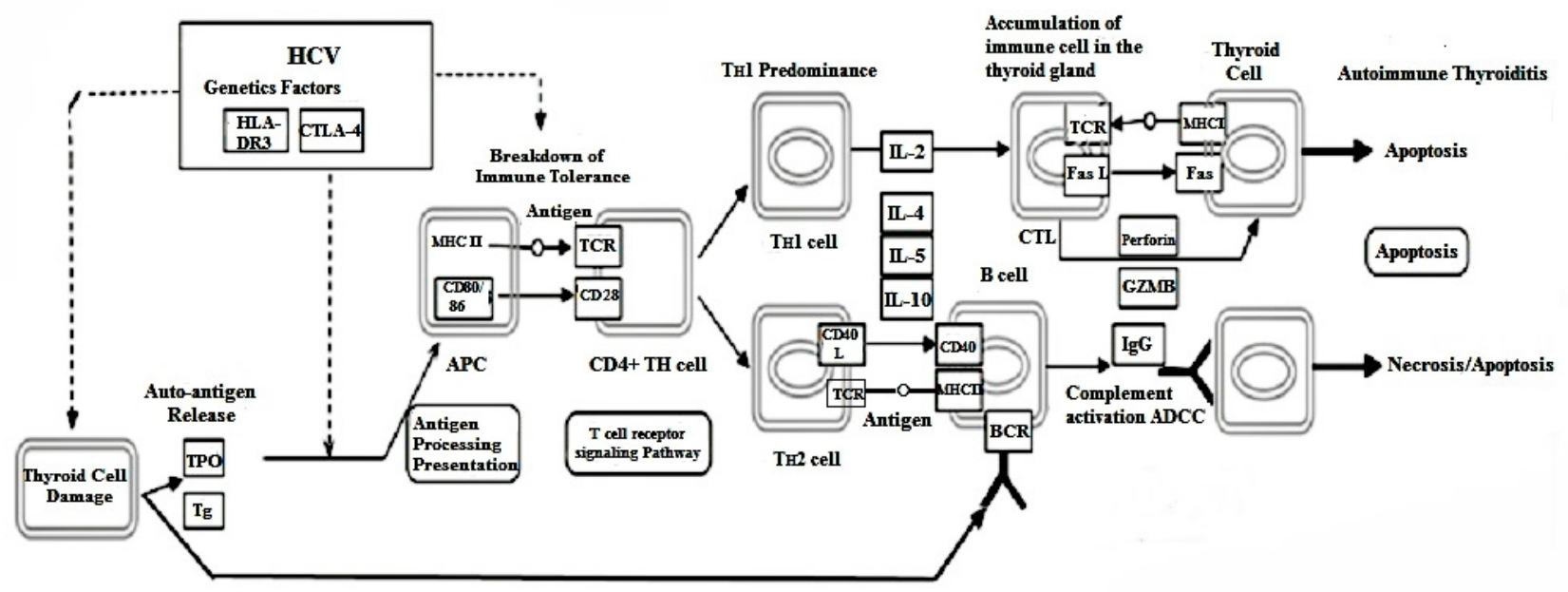

Figure 1. Potential targets for the hepatitis $C$ virus-mediated autoimmune thyroiditis - Signaling pathway. Source: Research data.

The potential targets for the hepatitis $\mathrm{C}$ virus-mediated AIT are triggered by linkage among Human Leukocyte Antigen-DR3, cytotoxic T-lymphocyte-associated protein 4 (CTLA-4) and auto-antigens on human thyroid cells, associated to breakdown of immune tolerance and antigen processing presentation, triggering intracellular signals, that leads to $\mathrm{T}$ helper cells responses, with $\mathrm{T}$ helper cell 1 predominance, activation of IL-2, IL4, IL-5 and IL-10 involved in immune responses to viral infection, immune cell accumulation of Fas-ligand also involved in apoptosis of immune cells, T-cell receptor, and major histocompatibility complex in the thyroid gland, presenting as final result the onset of AIT and thyroid cells apoptosis.

\section{DISCUSSION}

It has been hypothesized that individuals with genetic susceptibility for AIT exposed to HCV infection may develop thyroiditis. The HCV is both hepatic- and lymphotropic virus which triggers hepatic and extra hepatic manifestations including numerous autoimmune/lymphoproliferative and/or neoplastic disorders. ${ }^{9}$ We show the signaling pathway of TPO and $\mathrm{Tg}$, and their potential targets for the HCV-mediated AIT.

Breakdown of immune tolerance due to chronic HCV infection occur due to a lack or deficiency of subpopulation of regulatory T-cells with suppressive function, and the CTLA-4 plays a crucial role taking to maintain self-tolerance leading to initiation of a primary autoimmune response. ${ }^{10}$

The HCV infection can cause thyroid cell damage in genetically susceptible individuals by an immune response, with a nonspecific production of tumor necrosis factor-a (TNF-a) secondary, thereby increasing the MHC class expression on a cell membrane, making these cells seems like antigen presenting cells (APC) increasing antibodies production against TPO and $\mathrm{Tg} .{ }^{11}$ Thus, in the initial stage, agglutination of MHC class II positive APC in the thyroid, that present thyroid-specific autoantigens to T-cells with clonal expansion and full development of autoreactive T and B lymphocytes. ${ }^{12}$

The antigens produced by the HCV through an interaction of membrane $\mathrm{T}$-cells receptors (TCR) are recognized by the T-cells that are activated resulting in greater expression of the CTLA- 
4 molecule that shares homology with CD28, in this way it acts as a competitive inhibitor to CD28 besides acting as negative regulator of T-cell activation. ${ }^{13}$ Another important aspect is that an increase of CTLA-4 that can inhibit the early T-cell activation by blocking the interaction of CD80/ CD86 with the co-stimulatory receptor CD28, and the increased expression of co-stimulatory molecules CD80/86 arising from transport of MHC molecules to the cell surface has been established during an immune response. ${ }^{14,15}$

The T-cells CD4+ execute important functions in the pathogenesis of AIT. ${ }^{16}$ After the identification of autoantigens by the lymphocytes, an exaggerated increase will occur in the production of autoreactive CD4+ T-cells because they are excessively stimulated, as well as immunoglobulin $\mathrm{G}$ (IgG) autoantibodies, and CD8+ cytotoxic T- cells. ${ }^{17}$

Recently was showed that HCV envelope protein E2 induces strong inflammatory responses in thyroid cells, producing interleukin (IL)-8, IL-6, and TNF-a. Besides that, the E2 protein induces production of other proteins as Heat Shock Protein (HSP)60, HSP70p12A, and HSP10, in the primary thyrocytes. ${ }^{18}$

The Th1 cells stimulate autoimmune inflammatory reactions stimulating APC, and secrete IL-2, IFN- $Y$, and TNF- $a$, whereas Th2-cells enhance the production of autoantibodies and secrete IL4, IL-5, IL-6, IL-10. The TCR affinity will determine whether the immune response will be by Th1 or Th2 cells. ${ }^{19}$ Thus, the preservation of thyroid cells by the induction of anti-apoptotic and pro-apoptotic proteins is regulated by Th1-cells or Th2-cells. The initial process of apoptosis of thyroid cells in AIT is TH1 cells-mediated by mechanisms involvement cytokine-regulated apoptotic pathways, and involvement of death receptors cell. ${ }^{20}$

The B-cells can internalize an antigen linking to the $\mathrm{B}$-cell receptors (BCR) incorporating it into the MHC II molecule. Low antigen concentrations make the $B$ cells to function as superior $A P C$, and capture antigen with antigen-specific $B C R$, concentrating the immune response in a specific antigen, while macrophages and dendritic cells perform pinocytosis of antigen. ${ }^{21}$

The AIT has as a histological feature accumulation of immune cells in the thyroid gland, leading to disease progression, since central tolerance causes self-reactive $T$ cells to accumulate in the thyroid by altering the site of immunoregulation with secretion of lymphokines or cytolysis. ${ }^{22}$ The thyroid disorders due HCV infection increases the CXCL10 expression of thyroid cells, with a grouping of Th1 lymphocytes into the gland, unleashing the onset of AIT in individuals with risk factors as well as in predisposed individuals. ${ }^{23}$

The Fas (CD95, TNF receptor superfamily member 6) is membrane receptor that belongs to the TNF-a family of death receptors that intermeddles T-cells responses, and T-cell-mediated cytotoxicity happens due to mechanisms Fas-dependent cytotoxicity and perforin/GZMB. ${ }^{24}$ The Fas/Fas ligand interaction among thyrocytes favors for the pathogenesis of AIT with apoptotic cell death. ${ }^{25}$

The complement activation of antibody-dependent-cell-cytotoxicity carry antibodies to target cells including those against TPO and $\mathrm{Tg}$ mediated by IgG, but other unknown antibody-antigen complexes may also contribute to thyroid cell destruction. ${ }^{26}$.

\section{CONCLUSION}

The interaction between genetics factors HC$\mathrm{V}$-related and auto-antigens on human thyroid cells that express the main HCV receptors on their surface, in conjunction with breakdown of immune tolerance and antigen processing presentation, triggering intracellular signals, leading to $T$ helper cells responses and activation of IL involved in immune responses to viral infection and immune cell accumulation in the thyroid gland, the end result being the onset of AIT.

Thus, the data indicate that HCV infection acts in the breakdown of immune tolerance unleashing thyroid cell damage through of an auto-antigen released against TPO and $\mathrm{Tg}$, with activation of several signaling pathways resulting in AIT and secondary hypothyroidism to cellular apoptosis.

\section{REFERENCES}

1. Paek E, Park J, Lee KJ. Multi-layered representation for cell signaling pathways. Mol Cell Proteomics. 2004;3(10):1009-22.

2. Brent GA. Mechanisms of thyroid hormone action. J Clin Invest. 2012;122(9):3035-43. 
3. Andrade LJ, Atta AM, Atta $M L$, Mangabeira CN, Paraná R. Thyroid disorders in patients with chronic hepatitis C using interferon-alpha and ribavirin therapy. Braz J Infect Dis. 2011;15(4):377-81.

4. Andrade LJ, D'Oliveira A Jr, Silva CA, et al. A meta-analysis of patients with chronic hepatitis $C$ treated with interferon-alpha to determine the risk of autoimmune thyroiditis. Acta Gastroenterol Latinoam. 2011;41(2):104-10.

5. Obołończyk $\measuredangle$, Siekierska-Hellmann M, Wiśniewski $P$, et al. Epidemiology, risk factors and prognosis of Interferon alpha induced thyroid disorders. A Prospective Clinical Study. Postepy Hig Med Dosw (Online). 2017;71(0):842-849.

6. Blackard JT, Kong L, Huber AK, Tomer Y. Hepatitis C virus infection of a thyroid cell line: implications for pathogenesis of hepatitis $C$ virus and thyroiditis. Thyroid. 2013;23(7):863-70.

7. Ogata H, Goto S, Sato K, Fujibuchi W, Bono H, Kanehisa M. KEGG: Kyoto Encyclopedia of Genes and Genomes. Nucleic Acids Res. 1999;27(1):29-34.

8. Kutmon M, van Iersel MP, Bohler A, et al. PathVisio 3: an extendable pathway analysis toolbox. PLoS Comput Biol. 2015;11(2):e1004085.

9. Ferri C, Colaci M, Fallahi P, Ferrari SM, Antonelli A, Giuggioli D. Thyroid Involvement in Hepatitis C Virus-Infected Patients with/without Mixed Cryoglobulinemia. Front Endocrinol (Lausanne). 2017;8:159.

10. Vasu C, Gorla SR, Prabhakar BS, Holterman MJ. Targeted engagement of CTLA-4 prevents autoimmune thyroiditis. Int Immunol. 2003;15(5):641-54.

11. Tomoyose T, Komiya I, Takara M, et al. Cytotoxic T-lymphocyte antigen-4 gene polymorphisms and human T-cell lymphotrophic virus-1 infection: their associations with Hashimoto's thyroiditis in Japanese patients. Thyroid. 2002;12(8):673-7.

12. Many MC, Maniratunga S, Varis I, Dardenne M, Drexhage HA, Denef JF. Two-step development of Hashimoto-like thyroiditis in genetically autoimmune prone non-obese diabetic mice: effects of iodine-induced cell necrosis. J Endocrinol. 1995;147(2):311-20.

13. Patsoukis N, Weaver JD, Strauss L, Herbel C, Seth $P$, Boussiotis VA. Immunometabolic Regulations Mediated by Coinhibitory Receptors and Their Impact on $\mathrm{T}$ Cell Immune Responses. Front Immunol. 2017;8:330.
14. Marguerie C, Lunardi C, So A. PCR-based analysis of the TCR repertoire in human autoimmune diseases. Immunol Today. 1992;13(9):336-8.

15. Salomon B, Bluestone JA. Complexities of CD28/B7: CTLA-4 costimulatory pathways in autoimmunity and transplantation. Annu Rev Immunol. 2001;19:225-52.

16. Weetman AP. An update on the pathogenesis of Hashimoto's thyroiditis. J Endocrinol Invest. 2020 Dec 17.

17. Pyzik A, Grywalska E, Matyjaszek-Matuszek B, Roliński J. Immune disorders in Hashimoto's thyroiditis: what do we know so far? J Immunol Res. 2015;2015:979167.

18. Hammerstad SS, Stefan M, Blackard J, et al. Hepatitis C Virus E2 Protein Induces Upregulation of IL-8 Pathways and Production of Heat Shock Proteins in Human Thyroid Cells. J Clin Endocrinol Metab. 2017;102(2):689-697.

19. Kaiko GE, Horvat JC, Beagley KW, Hansbro PM. Immunological decision-making: how does the immune system decide to mount a helper T-cell response? Immunology. 2008; 123(3):326-38.

20. Tomer Y. Genetic dissection of familial autoimmune thyroid diseases using whole genome screening. Autoimmun Rev. 2002;1(4):198-204.

21. Harvey BP, Gee RJ, Haberman AM, Shlomchik MJ, Mamula MJ. Antigen presentation and transfer between $B$ cells and macrophages. Eur J Immunol. 2007;37(7):1739-51.

22. Armengol MP, Sabater $L$, Fernández $M$, et al. Influx of recent thymic emigrants into autoimmune thyroid disease glands in humans. Clin Exp Immunol. 2008;153(3):338-50.

23. Ferrari SM, Fallahi P, Antonelli A, Benvenga S. Environmental Issues in Thyroid Diseases. Front Endocrinol (Lausanne). 2017;8:50.

24. Du W, Cao X. Cytotoxic Pathways in Allogeneic Hematopoietic Cell Transplantation. Front Immunol. 2018;9:2979.

25. Yamada A, Arakaki R, Saito M, Kudo Y, Ishimaru N. Dual Role of Fas/FasL-Mediated Signal in Peripheral Immune Tolerance. Front Immunol. 2017;8:403.

26. Hidaka $Y$, Amino $N$, Iwatani $Y$, et al. Increase in peripheral natural killer cell activity in patients with autoimmune thyroid disease. Autoimmunity. 1992;11(4):239-46. 


\section{Competing Interests}

The authors declare that they have no potential conflict of interest.

Corresponding Author:

Gabriela Correia Matos de Oliveira

gabrielacorreiamo@gmail.com

Editor:

Prof. Dr Felipe Villela Gomes

Received in: sep 20, 2020

Approved in: $\operatorname{mar} 24,2021$

(c) (i) Este é um artigo publicado em acesso aberto (Open Access) sob a licença Creative

sem restrições, desde que o trabalho original seja corretamente citado. 